\title{
Comfort zones
}

\section{Editor}

Joe Bouch

$\begin{array}{lll}\begin{array}{ll}\text { Editorial Board } \\ \text { Gwen Adshead }\end{array} & \begin{array}{l}\text { Cornelius Katona } \\ \text { Helen Killaspy }\end{array} & \begin{array}{l}\text { Editorial Assistant } \\ \text { Jonica Thomas }\end{array} \\ \text { J.S. Bamrah } & \text { David Owens } & \\ \text { Dinesh Bhugra } & \text { Femi Oyebode } & \text { Staff Editors } \\ \text { Nick Brown } & \text { Jan Scott } & \text { Kasia Krawczyk } \\ \text { Alistair Burns } & \text { Tom Sensky } & \text { Lynnette Maddock } \\ \text { Patricia Casey } & \text { Steven Sharfstein } & \text { Zosia O'Connor } \\ \text { John Cookson } & \text { Michael Smith } & \\ \text { Colin Drummond } & \text { Peter Tyrer } & \\ \text { Jonathan Green } & \text { David Yeomans } & \\ \text { Sheila Hollins } & & \end{array}$

Subscriptions

Advances Volume 16, 2010 (six issues)

(full airmail £19/US\$34 extra)

\begin{tabular}{|c|c|c|c|}
\hline & $\begin{array}{l}\text { Members of the } \\
\text { Royal College } \\
\text { of Psychiatrists }\end{array}$ & Non-members & Institutions \\
\hline \multicolumn{4}{|c|}{ Print (+free online) } \\
\hline Europe (\& UK) & $f 62$ & f130 & f141 \\
\hline USA & US\$110 & US\$205 & US\$243 \\
\hline Elsewhere & f69 & $£ 140$ & £152 \\
\hline \multicolumn{4}{|l|}{ Online (only) } \\
\hline Worldwide & £39/US\$63 & £103/US\$155 & f128/US\$199 \\
\hline
\end{tabular}

Payment may be made by cheque/money order, by Access/Master Card/ Visa/American Express, or by UNESCO coupons. EC subscribers: please supply your Member State Code and Value Added Tax (VAT) number.

Payment should be made to Maney Publishing, Suite 1C, Joseph's Well, Hanover Walk, Leeds LS3 1AB, UK (tel: +44 (0)113 243 2800; fax: +44 (0)113 386 8178; email: subscriptions@maney.co.uk). For subscriptions in North America, please contact Maney Publishing North America, 875 Massachusetts Avenue, 7th Floor, Cambridge, MA 02139, USA (tel: 866 2975154 (toll-free); fax: 617354 6875; email: maney@maneyusa.com).

Continuing professional development (CPD) Those wishing to register for CPD with the Royal College of Psychiatrists should contact the CPD unit (tel: +44 (0)20 72352351 , ext. 108 or 112). There is no charge for participation in the CPD scheme for Members, Fellows and Affiliates of the College.

CPD Online The College also publishes an interactive online learning facility for CPD in psychiatry. Further details, sample modules and subscription information can be viewed at www.psychiatrycpd.co.uk. Discounts are available for Advances subscribers.

Correspondence Letters submitted for publication should be emailed to Dr Joe Bouch at apt@rcpsych.ac.uk or posted to Advances in Psychiatric Treatment, Royal College of Psychiatrists, 17 Belgrave Square, London SW1X 8PG.

Printed by Henry Ling Ltd, 23 High East Street, Dorchester, Dorset DT1 1 HD.

(C) The Royal College of Psychiatrists 2010. Published by the Royal College of Psychiatrists, a charity registered in England and Wales (228636) and in Scotland (SC038369). Unless so stated, material in Advances in Psychiatric Treatment does not necessarily reflect the views of the Editor or the Royal College of Psychiatrists. The publishers are not responsible for any errors of omission or fact.

The College crest is a registered trade mark of the Royal College of Psychiatrists.

ISSN $1355-5146$

\section{By Joe Bouch}

It is a great pleasure to greet colleagues from the Royal Australia and New Zealand College of Psychiatrists (RANZCP). The RANZCP has just made the decision to purchase online access to Advances for its 3000 members. This is welcome news for more than one reason. We have always had a steady stream of subscribers and some excellent papers from Australasian authors. I hope that this will lead to more, raising our international awareness and contributing to Advance's broad educational agenda. In addition, as we do not carry paid advertisements we depend on individual and institutional subscriptions for our financial survival. At a time of great concern in the medical profession about the sponsorship of medical education our financial independence is a considerable strength.

One of the reasons that Advances takes a broad educational approach is that psychiatric disorders are no respecters of either service boundaries or gaps in the evidence base. Reading outwith the comfort zone of one's own specialty is vital. This issue features articles on two important conditions with onset in childhood but which persist into adulthood and may manifest differently there. Howlin (pp. 133-140) considers psychological treatments for autism-spectrum disorders, focusing on children, while Janakiraman \& Benning (pp. 96-104) consider attentiondeficit hyperactivity disorder (ADHD) in adults. Both are common. The respective prevalences, which may be around $1 \%$ and $2 \%$ of the adult population, and the frequency of psychiatric comorbidities mean that all clinicians working in mental health services should be familiar with them. So too should clinicians be alert to a vulnerable group who may be 'invisible' (Oates 1997) and who are the focus of the article by Cooklin (pp. 141-146), which is my Editor's pick this month.

\section{Young carers}

The children of parents who have a severe mental illness are at a much increased risk of developing that illness themselves. Coupled with this is the negative impact on their social and cognitive development that can result from one or both parents being ill. Cooklin highlights that although young carers should be everyone's responsibility, in reality they are often no one's. Mental health staff used to working with adults feel untrained and nervous that they might say the wrong thing. Compounding the problem is that these children are used to being ignored and to coping by themselves, sometimes at the expense of developing 'false maturity'. A group of young carers reported to the author that worst for them was that their knowledge and advice were not sought by anyone "when the mental health services suddenly realised there was a problem and became involved'. Smith and colleagues (pp. 147-154) show that 'psychoeducation' can be a powerful intervention for patients with bipolar disorder that modifies the course of the illness. For young carers, simply appropriately discussing their parent's illness with them can have a significant protective impact. Perhaps another reason for us all to be prepared to leave our comfort zones?

Oates M (1997) Patients as parents: the risk to children. British Journal of Psychiatry 170 (suppl 32): 22-7. 